\title{
Intermediate Zone Cells Express Calcium-Permeable AMPA Receptors and Establish Close Contact with Growing Axons
}

\author{
Christine Métin, ${ }^{1}$ Jean-Pierre Denizot, ${ }^{2}$ and Nicole Ropert ${ }^{2}$ \\ ${ }^{1}$ Equipe Régionalisation Nerveuse, Centre National de la Recherche Scientifique (CNRS) Unité Mixte de Recherche 8542 , \\ Niveau 8, Ecole Normale Supérieure, 75230 Paris Cédex 05, France, and 2Institut Alfred Fessard, CNRS Unité Propre de \\ Recherche 2212, 91198 Gif sur Yvette, France
}

Recent studies have shown that cells in the intermediate zone (IZ) of the embryonic neocortex originate in the basal telencephalon and migrate tangentially in the cortical wall (Anderson et al., 1997; Tamamaki et al., 1997; Wichterle et al., 1999). We had previously observed growing cortical axons closely apposed to calbindin-positive, tangentially oriented cells in the IZ (Métin and Godement, 1996), and it has been shown that neurites in the IZ express a glutamate transporter (Furuta et al., 1997). To test if glutamate released by corticofugal growth cones could influence the tangential IZ cells, we characterized the glutamate receptors expressed by IZ cells using patchclamp techniques, histochemical labeling, and immunostaining on slices of embryonic mice forebrain. We show that tangential IZ cells express inwardly rectifying kainate responses, but not NMDA responses, and accumulate cobalt after AMPA receptor activation. We conclude that IZ cells express calcium- permeable AMPA receptors. This property correlates with our observation that the GluR2 subunit is not expressed in the IZ.

AMPA receptors are activated by a millimolar concentration of glutamate. To know whether this high level of glutamate could occur at the surface of $I Z$ cells, we examined contacts made by corticofugal growth cones and calbindin-positive IZ cells using electron microscopy. We show vesicle-containing neurites tightly apposed to calbindin-positive IZ cells over remarkably long length. This suggests that glutamate released by growing corticofugal axons could reach high concentrations close to AMPA receptors of tangential IZ cells and efficiently activate them to control the intracellular calcium in embryonic $\mathrm{IZ}$ cells.

Key words: cortex; development; tangential migration; cortical plate; glutamate; calcium permeability; cyclothiazide; LY303070; GYKI 53784; GABA; GABA $_{A}$ receptors; mouse
The intermediate zone (IZ) of the developing mammalian cortex extends between the ventricular zone (VZ) where proliferation occurs, and the cortical plate $(\mathrm{CP})$ where neurons differentiate after their radial migration. The IZ is a region of tangential migration of cells, in particular of GABAergic cells (Van Eden et al., 1989; Altman and Bayer 1990; Cobas et al., 1991; Del Rio et al., 1992; Tan et al., 1998), generated outside the cortical wall, in the ganglionic eminence (GE) of the basal telencephalon (Anderson et al., 1997; Tamamaki et al., 1997; Wichterle et al., 1999). The growth cones of cortical efferent and afferent axons also migrate in the IZ (Miller et al., 1993; Métin and Godement, 1996; Molnar et al., 1998). Finally, at midgestation, the lower part of the IZ becomes a secondary proliferative zone, the subventricular zone (Takahashi et al., 1995). Therefore, the IZ is not only a cortical zone devoted to the tangential traffic of cells and growth cones, but may also play an important role in cortical neurogenesis.

Corticofugal axons extend in the lower IZ among tangential

\footnotetext{
Received July 26, 1999; revised Oct. 15, 1999; accepted Oct. 22, 1999.

This work was supported by grants from the European Community (ERB BIO 4CT960146) and Human Frontier Science Program (RG83/96) to M.W., and from the Association Franco-Israelienne pour la Recherche Scientifique et Technologie (970MAEN07) to N.R. We thank Marion Wassef for strong support and helpful discussions and Monique Thomasset for the gift of calbindin antiserum. We also thank Douglas Frost, Patricia Gaspar, Richard Miles, and Boris Barbour for critically reading this manuscript.

Correspondence should be addressed to Christine Métin, Equipe Régionalisation Nerveuse, Centre National de la Recherche Scientifique Unité Mixte de Recherche 8542, Niveau 8, Ecole Normale Supérieure, 46 rue d’Ulm, 75230 Paris Cédex 05, France. E-mail: metin@biologie.ens.fr.

Copyright (C) 2000 Society for Neuroscience $0270-6474 / 00 / 200696-13 \$ 15.00 / 0$
}

calbindin-positive cells, and close appositions occur between growth cones of corticofugal axons and calbindin-positive IZ cells that are suggestive of specific interactions (Métin and Godement, 1996). Cellular interactions during development have been shown to involve either nondiffusible signaling molecules mediating short-range communication as in the delta/notch and ephrin/Eph receptor pathways (Beatus and Lendahl, 1998; Flanagan and Vanderhaeghen, 1998) or long-distance signaling molecules such as morphogens (Mehler et al., 1997) and diff usible guidance molecules (Tessier-Lavigne and Goodman, 1996).

At early embryonic stages, neurotransmitters are believed to mediate long-range interactions (LoTurco et al., 1991; Komuro and Rakic, 1993; Zheng et al., 1994; Behar et al., 1996). Glutamate, the main excitatory neurotransmitter in adult cortex, is accumulated in embryonic cortical cells and tangential fibers in the IZ (Herrmann, 1996) and can be released by growth cones (Soeda et al., 1997). Glutamate transporters are expressed by embryonic cortical cells (Furuta et al., 1997). Glutamate has been shown to modulate cell proliferation (LoT urco et al., 1995; Gallo et al., 1996), radial migration (Komuro and Rakic, 1993), and growth cone motility (Owen and Bird, 1997). Embryonic cortical cells express a variety of glutamate receptor subunits that could form receptors with different functional properties (Hollmann and Heinemann, 1994), but the cellular distribution of most glutamate receptor subunits in the embryonic cortex, in particular in the IZ, is unknown.

We therefore characterized the glutamate receptors expressed by IZ cells using patch-clamp recordings and neuroanatomical techniques. We show that tangential IZ cells express calcium- 
permeable AMPA receptors. At the ultrastructural level, we show that growing corticofugal fibers containing clear vesicles are tightly apposed to calbindin-positive IZ cells. This suggests that glutamate released from cortical fibers could activate the lowaffinity AMPA receptors and mediate a calcium influx to IZ cells. This represents a novel short-range interaction mediated by a neurotransmitter that may influence the migration and fate of cortical cells during development.

\section{MATERIALS AND METHODS}

Preparation of embryonic brain slices. Timed pregnant OF1 and C57BL mice were killed at 12,13 , and $14 \mathrm{~d}$ of gestation [embryonic day 12.5 (E12.5), E13.5, and E14.5, respectively; date of the plug $=\mathrm{E} 0.5]$ by cervical elongation after light ether anesthesia. The uterus and embryos were removed. To prepare $250-\mu \mathrm{m}$-thick slices with a McIllwain tissue chopper, the embryonic brains were rapidly isolated in cold oxygenated $\left(5 \% \mathrm{pCO}_{2}\right.$ and $95 \% \mathrm{pO}_{2}$ ) artificial CSF (ACSF) with $10 \mathrm{~mm}$ lactate. The telencephalic vesicles were dissected, the olfactory bulbs and hippocampi were removed, and telencephalic vesicles were sectioned in the coronal plane. To prepare slices with a vibratome (DTK-1000; DSK), the brains were first embedded in 5\% type VII agar in L15 medium (Life Technologies, Gaithersburg, MD), and sectioned in the frontal plane in cold oxygenated ACSF with $10 \mathrm{~mm}$ lactate, which was added to facilitate the neuronal recovery from hypoxia caused by slice preparation (Schurr et al., 1997).

Histochemical studies. Cobalt $\left(\mathrm{Co}^{2+}\right)$ uptake was revealed using the Pruss reaction (Pruss et al., 1991), with ammonium sulfide 1\% (NH4)2S in uptake buffer to precipitate $\mathrm{Co}^{2+}$. The slices were rinsed for half an hour in uptake buffer at room temperature and incubated for $30 \mathrm{~min}$ in $10 \mathrm{mM} \mathrm{CoCl}_{2}$ uptake buffer either alone or in the presence of $250 \mu \mathrm{M}$ kainate (KA). The following substances were added to test the specificity of the KA-induced $\mathrm{Co}^{2+}$ uptake: $100 \mu \mathrm{M}$ cyclothiazide $(\mathrm{CTZ}) ; 100 \mu \mathrm{M}$ 6,7-dinitroquinoxaline-2,3-dione (DNQX); and $20 \mu \mathrm{M}$ of a 2,3 benzodiazepine (LY303070) in the presence or in the absence of $100 \mu \mathrm{M} \mathrm{CTZ.}$ Stained sections were rinsed in uptake buffer, fixed in $4 \%$ paraformal-

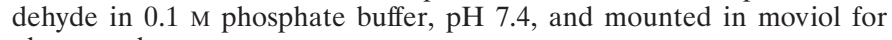
photography.

Intracellular recordings and data analysis. The slices were maintained for at least $1 \mathrm{hr}$ in standard oxygenated $\left(5 \% \mathrm{pCO}_{2}\right.$ and $\left.95 \% \mathrm{pO}_{2}\right) \mathrm{ACSF}$ at $35^{\circ} \mathrm{C}$ with $10 \mathrm{~mm}$ lactate before recording. Cells were identified using an upright fixed stage microscope (Axioskop, Zeiss) with Nomarski optics (IR-Achroplan $40 \times$ ) and an infrared video camera (Newvicon; Hamamatsu, Tokyo, Japan). Recordings were obtained at room temperature $\left(22-25^{\circ} \mathrm{C}\right)$ from submerged slices kept in place with platinum rods under constant $(2-3 \mathrm{ml} / \mathrm{min})$ perfusion of standard oxygenated ACSF.

Intracellular recordings were obtained with the patch-clamp technique in the whole-cell and nucleated-patch configurations. The signals were amplified and filtered at $2 \mathrm{kHz}$ (Axopatch 1D; Axon Instruments, Foster City, CA). The series resistance was not compensated. The signals were digitized at $2 \mathrm{kHz}$, stored on a computer on-line (Labmaster TL-1 DMA; Axon Instruments), and analyzed subsequently with a programmable software (Acquis 1; Biological). To obtain the current-voltage $(I-V)$ curve of the KA response, cells were maintained near their resting membrane potential $(-80 \mathrm{mV})$, and voltage ramps were applied for $2 \mathrm{sec}$ every 10 or $20 \mathrm{sec}$, between -80 and $+80 \mathrm{mV}$. The KA $I-V$ curve was calculated by subtracting the ramp response in control from that during the maximal KA response. When the KA responses were $>10 \mathrm{pA}$ at -80 $\mathrm{mV}$, the reversal potential $\left(V_{\text {rev }}\right)$ was calculated automatically as the zero intercept of the average response $(n=10-20)$. To quantify the rectification of the KA response, the relative chord conductance $(G)$, normalized to its value at $-80 \mathrm{mV}$, was calculated as follows: $G=[i \div(V-$ $\left.\left.V_{\text {rev }}\right)\right] \div\left[i \div\left(-80-V_{\text {rev }}\right)\right]$, where $i$ is the current measured at a given membrane voltage, $V$. The estimation of $G$ degenerates and is ignored near $V_{\text {rev. }}$.

The input resistance was estimated by applying current steps and calculating the slope of the $I-V$ curve by linear regression. Spike discharge was studied by applying the current steps from a holding potential between -80 and $-90 \mathrm{mV}$. Voltage-gated currents were evoked by holding the cell near $-80 \mathrm{mV}$ and by applying voltage steps of variable amplitude $(-20$ to $+80 \mathrm{mV}$ with steps of $10 \mathrm{mV})$. The $I-V$ curve of the voltage-gated currents was measured after leak subtraction of a small negative $(-10 \mathrm{mV})$ voltage step. Recording pipettes (resistance, 8-10 $\mathrm{M} \Omega$ ) were pulled from cleaned sterilized borosilicate glass and coated with beeswax. All results are given as mean $\pm \mathrm{SD}$. The unpaired Student's two-tailed $t$ test was used to examine the level of significance of the results.

Solutions and chemical compounds. The uptake buffer of the histochemical Pruss reaction contained (in $\mathrm{mm}$ ): sucrose, 139; $\mathrm{NaCl}, 57.5$; $\mathrm{KCl}, 5 ; \mathrm{MgCl}_{2}, 2 ; \mathrm{CaCl}_{2}$, 1; glucose, 12; and HEPES, 10; $\mathrm{pH}$, 7.6. The standard ACSF contained (in $\mathrm{mM}$ ): $\mathrm{NaCl}, 126 ; \mathrm{KCl}, 1.5 ; \mathrm{KH}_{2} \mathrm{PO}_{4}, 1.25$; $\mathrm{MgSO}_{4}, 1.5 ; \mathrm{CaCl}_{2}, 2 ; \mathrm{NaHCO}_{3}, 26$; and glucose, 10. The following compounds were added to ACSF: tetrodotoxin (TTX, $1 \mu \mathrm{M}$; Latoxan); cadmium chloride $\left(\mathrm{CdCl}_{2}, 200 \mu \mathrm{M}\right.$; Sigma, St. Louis, MO); KA (50-200 $\mu \mathrm{M}$; Tocris Cookson, Bristol, UK); CTZ (100 $\mu \mathrm{M}$; Tocris); DNQX (10 $\mu \mathrm{M}$; Tocris); and LY303070 (GYKI 53784, $20 \mu \mathrm{M}$; a generous gift from Lilly).

To record action potentials and potassium currents, the pipette solution contained (in mM): $\mathrm{K}$ gluconate, $144 ; \mathrm{MgCl}_{2}$, 3; ATP, 4; HEPES, 10 ; and EGTA, 0.5; $\mathrm{pH}, 7.35 ; 285-295 \mathrm{mOsm}$. To record the responses to agonists, the pipette solution contained (in mM): Cs gluconate, 120; $\mathrm{NaCl}, 10 ; \mathrm{CsCl}, 10 ; \mathrm{MgCl}_{2}, 2$; HEPES, 10; ATP, 4; and EGTA, 0.2 or 5; $\mathrm{pH}, 7.35 ; 285-295$ mOsm. Spermine tetrahydrochloride (100 $\mu \mathrm{M}$; Sigma) was added to the pipette solution of the nucleated-patch recordings. A correction of $+10 \mathrm{mV}$ was applied to compensate for the junction potential of the recording solution.

Immunocytochemistry and electron microscopy. Brains of E12.5-E14.5 embryos were fixed overnight at $4^{\circ} \mathrm{C}$ in $4 \%$ paraformaldehyde for light microscopy or $4 \%$ paraformaldehyde $0.1 \%$ glutaraldehyde for electron microscopy (EM) processing in $0.1 \mathrm{M}$ phosphate buffer (PB), pH 7.4. After embedding in agar, coronal vibratome sections (60- to $100-\mu \mathrm{m}-$ thick) were prepared and processed for immunostaining against calbindin (CaBP 28K; a generous gift of Dr. Monique Thomasset), the GluR1 AMPA subunit (GluR1; Chemicon, Temecula, CA) or the GluR2/3 AMPA subunits (GluR2/3; Chemicon), all rabbit polyclonal antibodies. Briefly, sections were treated with $1 \% \mathrm{H}_{2} \mathrm{O}_{2}$ in PBS to remove endogenous peroxidase activity, rinsed in PBS and incubated for at least $1 \mathrm{hr}$ in PGT (PBS with $0.2 \%$ gelatin and $0.1-0.2 \%$ Triton X-100). Sections prepared for EM observations were permeabilized with $0.01 \%$ saponin. Sections were incubated overnight at room temperature under agitation in primary antibodies diluted in PGT (1:5000 for CaBP 28K, 1:10 or 1:20 for GluR1, and 1:100 for GluR2/3). After rinsing in PBS, a biotinylated anti-rabbit IgG (Vector Laboratories, Burlingame, CA) diluted 1:200 in PGT was applied for $1 \mathrm{hr}$, followed by avidin-biotin-peroxidase immunostaining (ABC kit; Vector Laboratories). The immunolabeling was revealed using $0.035 \%$ diaminobenzidine (DAB) and $0.01 \% \mathrm{H}_{2} \mathrm{O}_{2}$ in 0.1 $\mathrm{M}$ Tris buffer, $\mathrm{pH}$ 7.4. In CaBP/GluR1 double-staining experiments, GluR1 was first revealed with DAB as substrate giving a brown staining. Then, CaBP was revealed in the presence of $0.02 \%$ nickel ammonium sulfate to color the DAB precipitate in gray. In control sections, no primary antibodies were applied. For EM, DAB-stained and control sections were post-fixed overnight in $0.1 \mathrm{M} \mathrm{PB}, \mathrm{pH} 7.8$, containing $0.25 \%$ osmium tetroxide and $0.75 \%$ potassium-perchlorate, dehydrated and embedded in Spurr's resin (TAAB). Carbocyanine [1,1'-dioctadecyl3,3,3',3'-tetramethyl-indocarbocyanine perchlorate (DiI); Molecular Probes, Eugene, OR] labeling of fibers was obtained as described in Métin and Godement (1996). Ultrathin sections $(80 \mathrm{~nm})$ were mounted on copper grids and observed without staining under a transmission electron microscope (Philips CM10).

\section{RESULTS}

Recordings were obtained from mouse embryonic cortical cells on E13.5 to E15.5 in acute slice preparation after identification by infrared video microscopy (Fig. $1 C, D$; see Fig. 8A1,B1). We recorded from IZ cells with tangentially oriented processes that either belong to cohorts of morphologically similar cells or appear isolated. In most IZ cells, we clearly observed a thick neurite that often bifurcated distally in the dorsal direction and a thinner neurite running ventrally toward the GE. In the CP we recorded from cells with a larger spherical soma and a thin neurite extending radially to deep cortical layers.

\section{Embryonic cortical neurons express functional AMPA receptors}

NMDA and non-NMDA glutamate receptor subunit mRNAs are present in cells of the embryonic cortical wall (Bettler et al., 1990; 

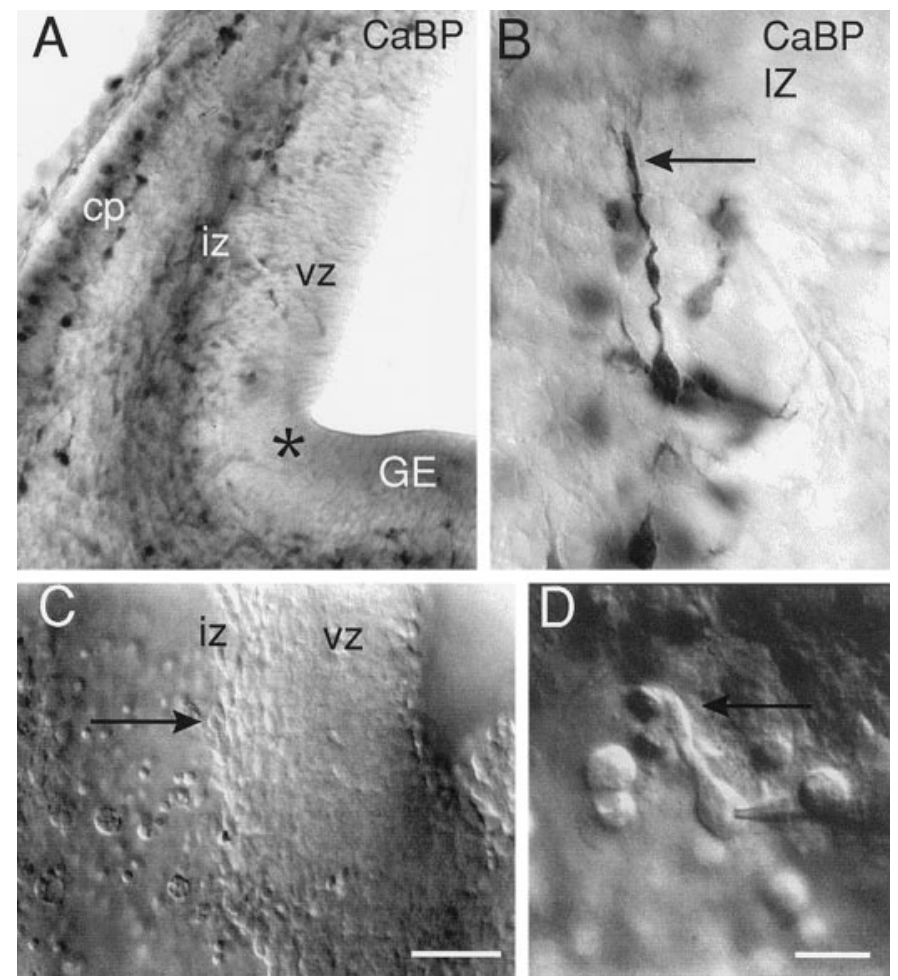

Figure 1. Identification of the tangential intermediate zone of the cortical wall. Coronal sections of E13.5 mouse telencephalic vesicle (dorsal up, medial right). $A, B$, Immunostaining of calbindin-positive $(C a B P)$ cells in the IZ of $100-\mu \mathrm{m}$-thick, fixed slices. $A$, Above the proliferative ventricular zone $(v z)$, in the lower half of the IZ (iz), labeled cells form a continuous row from the ventricular angle of telencephalon (asterisk) to the dorsal cortex. Positive cells outline the developing cortical plate $(c p)$. A few labeled cells are scattered in the vz. $G E$, Ganglionic eminence. $B$, Higher magnification view of a calbindin-positive IZ cell with a tangentially oriented thick process (arrow). C, D, Visualization of a live cortical slice preparation using Nomarski optics and infrared video microscopy. $C$, At low magnification, tangentially oriented cells of the IZ (arrow) form a dense cohort above the vz. Scale bar, $100 \mu \mathrm{m}$. $D$, At higher magnification, recording of a tangentially oriented IZ cell with a thick neurite (arrow) running dorsally. Scale bar, $10 \mu \mathrm{m}$.

Monyer et al., 1991; Burnashev et al., 1992; Herb et al., 1992; Bahn et al., 1994; Laurie and Seeburg, 1994). NMDA and AMPA/KA responses have been recorded in embryonic $\mathrm{CP}$ and VZ cells at early embryonic stage (LoTurco et al., 1991, 1995; Behar et al., 1999). IZ cells express GluR1 AMPA subunits (Herrmann, 1996), but their responses to glutamate have not been studied. In this study, we characterize the glutamate receptors expressed by IZ cells and by $\mathrm{CP}$ cells for a comparison.

To investigate the expression of non-NMDA receptors by embryonic IZ cells, we performed whole-cell recordings and applied in the perfusion medium KA, a nonselective agonist of AMPA and KA receptors that does not activate electrogenic glutamate transporters (Brew and Attwell, 1987). When the cells were maintained at $-80 \mathrm{mV}$, KA $(10-200 \mu \mathrm{M})$ induced a sustained inward current (Fig. 2A1) in most IZ (39 of 42) and all CP (19 of 19) cells. This response was reversible, reproducible, and dosedependent (Table 1). The KA-evoked current was maintained in the presence of blockers of the voltage-gated sodium and calcium currents ( $1 \mu \mathrm{M}$ TTX and $200 \mu \mathrm{M}$ cadmium; Fig. 2B), indicating that it is attributable to the direct activation of the AMPA/KA glutamate receptors expressed by the recorded $\mathrm{CP}$ and tangential IZ cells.
To examine whether IZ cells express NMDA receptors, the effect of bath applications of $100 \mu \mathrm{M}$ NMDA was tested in IZ cells that express KA responses $(n=4)$. Cells were tested in standard magnesium-containing medium and depolarized by a ramp from -80 to $+80 \mathrm{mV}$ to remove the voltage-dependent magnesium block (Fig. 2C3). We found that IZ cells do not respond to NMDA application $(n=7)$, which indicates that they express AMPA/KA receptors but lack NMDA receptors.

Kainate is a nonselective agonist of both AMPA and KA receptors. To identify the receptor type activated by KA in IZ and CP cells, we tested the effect of two ligands selective for AMPA receptors. We tested first the effect of a selective noncompetitive antagonist of AMPA receptors, the 2,3-benzodiazepine LY303070 or GYKI 53784 (Bleakman et al., 1996), on the response to KA of IZ $(n=4)$ and CP $(n=5)$ cells. LY303070 (20 $\mu \mathrm{M})$ by itself had no effect either on the holding current or on the ramp response, suggesting that the AMPA receptors expressed by these cells are not tonically activated by the extracellular glutamate in our recording conditions. In all cells, LY303070 blocked completely and reversibly the responses to $100 \mu \mathrm{M}$ KA (Fig. 3A). We also tested the effect of a selective antagonist of AMPA receptor desensitization, CTZ (Partin et al., 1993). CTZ (100 $\mu \mathrm{M})$ increased the whole-cell response to $100 \mu \mathrm{M} \mathrm{KA}$ in all IZ cells by $516 \pm 357 \%(n=4)$ and by $1100 \%$ in a CP cell (Fig. $3 B)$. In nucleated patches of IZ cells, we also compared the responses to $100 \mu \mathrm{M} \mathrm{KA}$ applied without and with $100 \mu \mathrm{M} \mathrm{CTZ}$ and found that the KA-induced inward current recorded at $-80 \mathrm{mV}$ was significantly smaller in control $(-4.6 \pm 5.3 \mathrm{pA} ; n=5)$ than in the presence of CTZ $(-253.8 \pm 328 \mathrm{pA} ; n=8)$. We conclude that $\mathrm{KA}$-induced inward current recorded in IZ and CP cells results from the activation of AMPA receptors.

IZ cells are GABAergic and could be involved in GABAmediated interactions. $\mathrm{GABA}_{\mathrm{A}}$ receptor subunits are expressed in cells of the embryonic cortical wall (Ma and Barker, 1998). Therefore, we looked at the expression of $\mathrm{GABA}_{\mathrm{A}}$ receptors by IZ cells. We studied the effect of GABA (50-200 $\mu \mathrm{M})$ and isoguvacine $(50 \mu \mathrm{M})$, a selective agonist of the $\mathrm{GABA}_{\mathrm{A}}$ receptors in the IZ and the CP. Most IZ (9 of 12) and CP (8 of 8) cells were responsive to GABA or isoguvacine. Both agonists induced a rapidly desensitizing response with a small inward current at -80 $\mathrm{mV}$ (Fig. 2C2). The $I-V$ curve of the GABA response recorded in IZ cells showed an outward rectification with a reversal potential at $-36.4 \pm 5.8 \mathrm{mV}(n=5)$ equal to the chloride equilibrium. These results indicate that IZ and CP cells express functional chloride permeable $\mathrm{GABA}_{\mathrm{A}}$ receptors.

\section{Intermediate zone neurons express calcium-permeable AMPA receptors}

AMPA receptor subunits are encoded by four genes (GluR1-4) with further diversity caused by alternative splicing and RNA

\section{Table 1. Dose-dependent effect of KA on CP and IZ neurons}

KA-induced current at $-80 \mathrm{mV}$

\begin{tabular}{lll}
$\begin{array}{l}\text { KA concentration } \\
(\mu \mathrm{M})\end{array}$ & $\mathrm{pA} \pm \mathrm{SD}(n)$ & $\mathrm{IZ}$ \\
\cline { 2 - 3 } 50 & $\mathrm{CP}$ & $-26 \pm 32(8)$ \\
100 & $-57 \pm 45(5)$ & $-65 \pm 77(25)$ \\
200 & $-110 \pm 92(14)$ & $-100 \pm 80(8)$
\end{tabular}

Bath applications of KA at increasing concentrations induce inward currents of increasing amplitude both in $\mathrm{CP}$ and tangential IZ cells. The inward current was measured at $-80 \mathrm{mV}$. 

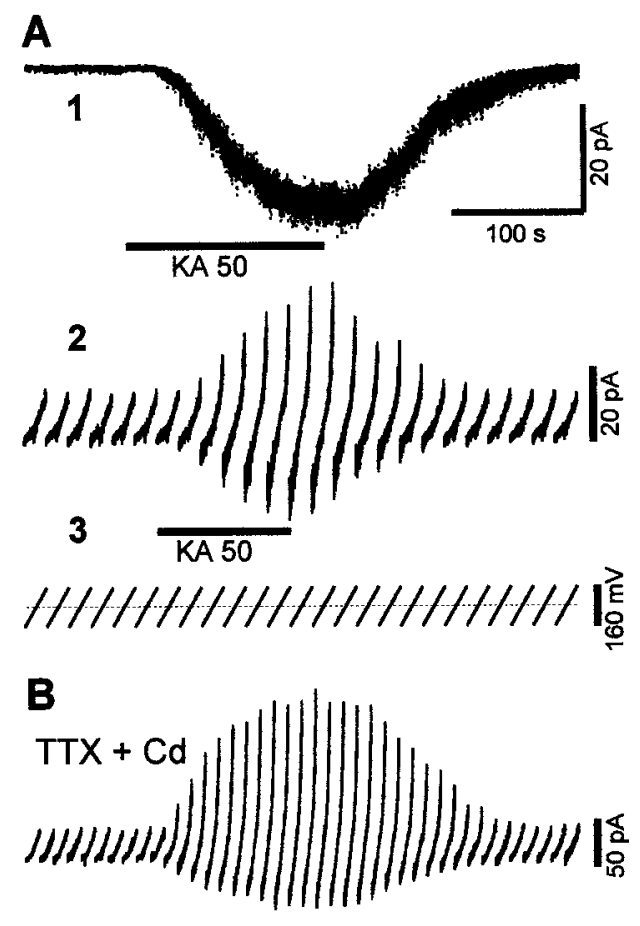

KA 100

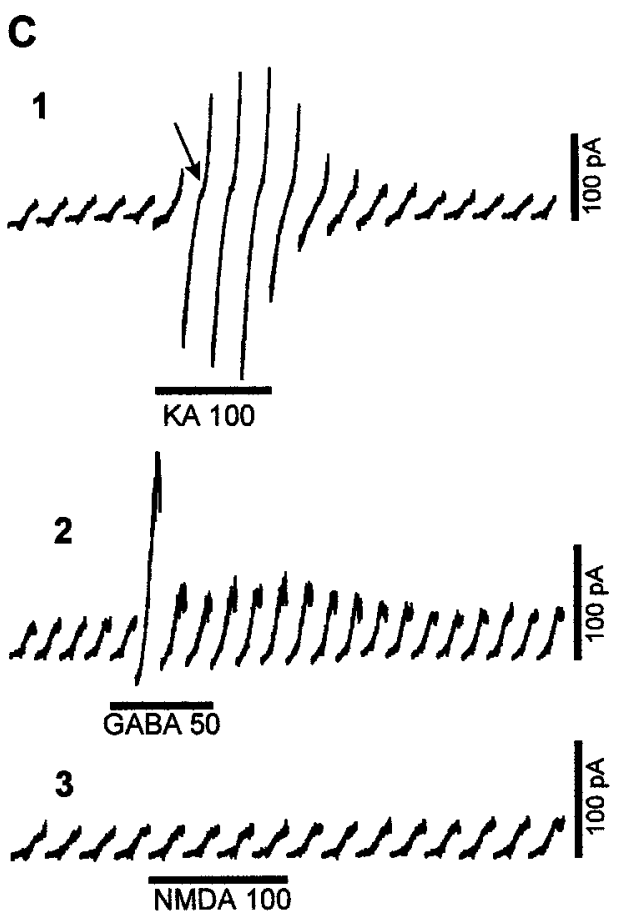

Figure 2. Responses to glutamate of E13.5-E14.5 cortical cells. Whole-cell recordings from IZ $(A, C)$ and $\mathrm{CP}(B)$ cells. $A 1$, Recording of an IZ cell maintained at $-80 \mathrm{mV}$ in control and during the bath application of $50 \mu \mathrm{M} \mathrm{KA}$ (thick line). KA induces a sustained inward (downward) current and an increase of the baseline noise that recovers after KA removal. 2, 3, In the same IZ cell, depolarizing ramps (3) from -80 to $+80 \mathrm{mV}$ are applied every $20 \mathrm{sec}$ during another $50 \mu \mathrm{M} \mathrm{KA}$ application; the continuous dotted line indicates $0 \mathrm{mV}$. In control, the cell responds to voltage ramps by a positive (upward) ramp current (2) of small amplitude corresponding to the cell input resistance. KA application (thick line) evokes a sustained inward current at $-80 \mathrm{mV}$, and the ramp response is increased as a result of KA-induced channel opening. $B$, In a CP cell, ramps are applied every $10 \mathrm{sec}$ during $100 \mu \mathrm{M} \mathrm{KA}$ application (thick line) in the presence of $1 \mu \mathrm{M}$ TTX and $200 \mu \mathrm{M} \mathrm{Cd}$; KA induces an inward current at $-80 \mathrm{mV}$ and a larger ramp response. $C$, In another IZ cell, depolarizing ramps from -80 to +80 $\mathrm{mV}$ are injected every $20 \mathrm{sec}$, and bath applications of $100 \mu \mathrm{M} \mathrm{KA}$ (1), $50 \mu \mathrm{M}$ GABA (2), and $100 \mu \mathrm{M}$ NMDA (3) are made. 1, KA (thick line) evokes a negative current at $-80 \mathrm{mV}$ and a larger ramp response with a clear deflection in the slope (arrow). 2, GABA (thick line) induces a small inward current at $-80 \mathrm{mV}$ and a transient increase of the ramp response followed by a smaller response caused by receptor desensitization. 3, NMDA (thick line) does not evoke any response. editing. Receptors exhibit different functional properties according to their subunit composition (Hollmann and Heinemann, 1994). AMPA receptors lacking the edited form of the GluR2 subunit show high calcium permeability (Ozawa et al., 1998). The GluR2 subunit is less frequent in embryonic than in older brain (Durand and Zukin, 1993), suggesting that calcium-permeable AMPA receptors are more abundant in embryos. We asked whether migrating IZ cells that lack calcium-permeable NMDA receptors express calcium-permeable AMPA receptors.

The calcium permeability of AMPA receptors is correlated with the rectification of their $I-V$ curve, the higher the calcium permeability, the larger the inward rectification (Ozawa et al., 1998). The rectification of the KA response was quantified by an index defined as follows. We first measured the $I-V$ curve of the
A control

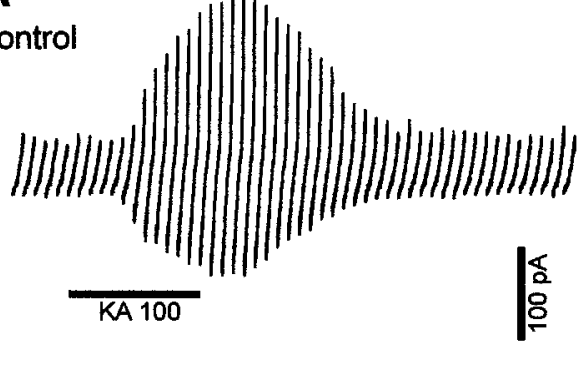

KA 100

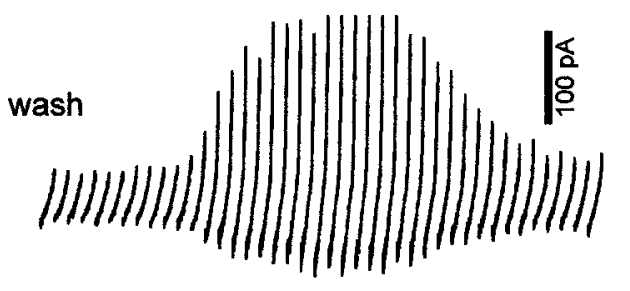

KA 100

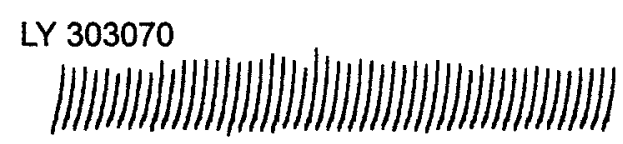

B

control

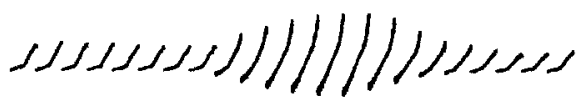

KA 100

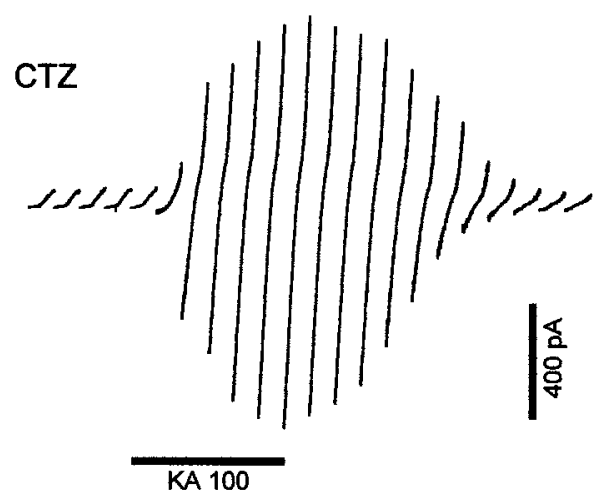

Figure 3. Kainate activates AMPA receptors in IZ and CP cells. $A$, Depolarizing ramps from -80 to $+80 \mathrm{mV}$ are applied every $10 \mathrm{sec}$ to an IZ cell, and $100 \mu \mathrm{M} \mathrm{KA}$ is applied (thick line); ramp responses are displayed in control, in the presence of $20 \mu \mathrm{M} \mathrm{LY303070,} \mathrm{and}$ after washout of LY303070. In control, KA evokes an inward current at -80 $\mathrm{mV}$ and an increase ramp response. LY303070 completely blocks the response to KA. The response to KA recovers after washing LY303070 for 10 $\min . B$, Ramps from -80 to $+80 \mathrm{mV}$ are applied every $20 \mathrm{sec}$ in a CP cell during $100 \mu \mathrm{M}$ KA application (thick line) in control and in the presence of $100 \mu \mathrm{M}$ CTZ. In control, KA induces an inward current at $-80 \mathrm{mV}$ and a larger response to the ramp. In CTZ, the inward current induced by KA at $-80 \mathrm{mV}$ and the ramp response are both increased. 


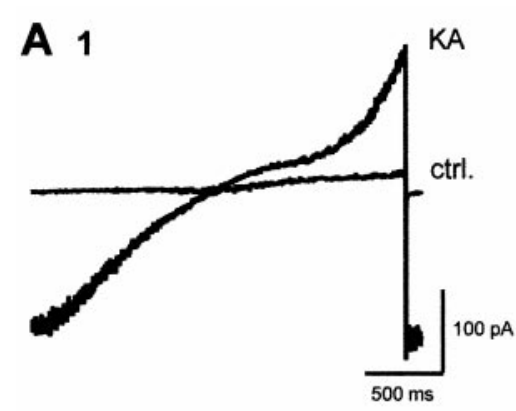

2

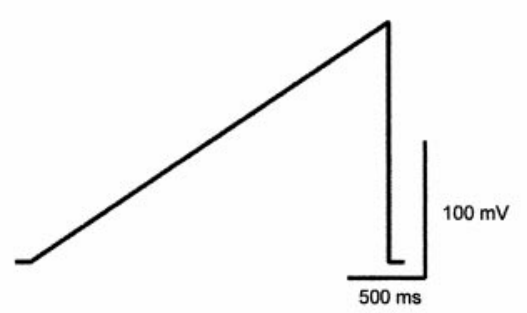

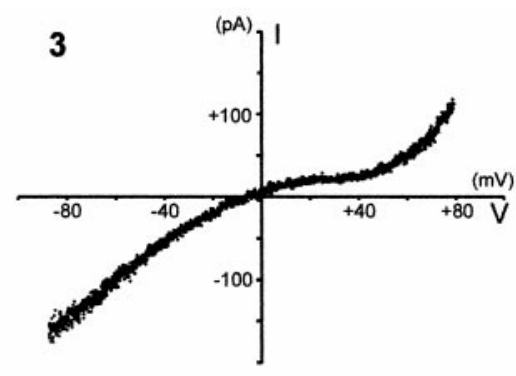

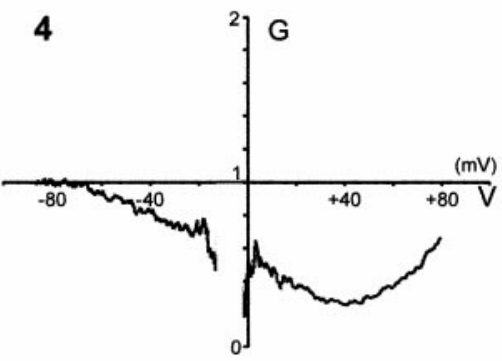

Figure 4. Rectification properties of AMPA receptors in $\mathrm{IZ}$ and $\mathrm{CP}$ cells. The $I-V$ curve of the KA response is shown for an IZ $(A)$ and a $\mathrm{CP}(B)$ cell. $A$, The response (1) to a depolarizing ramp between -80 and $+80 \mathrm{mV}$ of duration $2.2 \mathrm{sec}(2)$ is shown in control ( $\mathrm{ctrl}$ ) and during the maximal KA response $(K A)$. In control, the current ramp response is almost linear. During the KA application, an inward current $(\sim 150 \mathrm{pA})$ is evoked at $-80 \mathrm{mV}$, and the ramp response becomes nonlinear. 3, The $I-V$ curve of KA response is obtained by subtracting the $I-V$ curve in control from that in KA; the $I-V$ curve reverses at $-12 \mathrm{mV}$, and its slope diminishes between -70 and $+40 \mathrm{mV}$, displaying an inward rectification. 4 , The relative chord conductance, $G$, is plotted against the membrane potential, $V ; G$ reaches a minimum at $+40 \mathrm{mV}$ $\left(G_{+40}=0.267\right) . B$, KA response of a CP cell recorded in the presence of $1 \mu \mathrm{M}$ TTX and $200 \mu \mathrm{M}$ cadmium. 1, The $I-V$ curve reverses at $-7 \mathrm{mV}$ and is linear between -80 and $+40 \mathrm{mV}$ with an outward rectification above +40 $\mathrm{mV}$. 2, The relative chord conductance, $G$, is unchanged between -80 and $+40 \mathrm{mV}\left(G_{+40}=1.06\right)$. $C$, Distribution of the rectification index $\left(G_{+40}\right)$ for IZ and CP cells. 1 , All IZ cells display a strong inward rectification with $G_{+40}<0.70$. 2, In CP cells, more than half the cells ( 10 of 18) display outward rectification with $G_{+40}$ larger than one. When present, the inward rectification is on average weaker than in IZ cells.



C 1
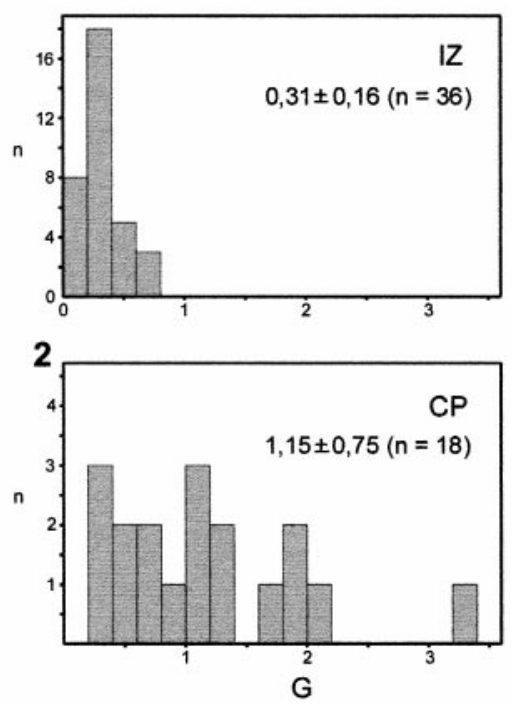

KA responses and calculated the relative chord conductance $(G)$ at different membrane potentials (Fig. 4). The minimal value of $G$ observed at $+40 \mathrm{mV}\left(G_{+40}\right)$ was then taken as the rectification index (Fig. 4A4). In all IZ cells, the KA $I-V$ curve displayed inward rectification (Fig. 4A3). In half the IZ cells (18 of 36), $\mathrm{G}_{+40}$ was $<0.25$, a value that has been used to define the AMPA receptors with high calcium permeability (Itazawa et al., 1997). In contrast, the KA $I-V$ curves of CP cells (Fig. 4C) displayed heterogeneous rectification index values with a mean value $\left(\mathrm{G}_{+40}=1.15 \pm 0.75 ; n=18\right)$ significantly $(p<0.001)$ different from that seen in IZ cells $\left(\mathrm{G}_{+40}=0.31 \pm 0.16 ; n=36\right)$. More than half the CP cells (10 of 18) displayed an outward rectification with a rectification index larger than one, typical of AMPA receptors with low calcium permeability. The other CP cells displayed an inward rectification with an index smaller than one, typical of AMPA receptors with intermediate or high calcium permeability. We conclude that embryonic IZ cells express only inwardly rectifying KA responses typical of calcium-permeable AMPA receptors. In $\mathrm{CP}$ cells, we find inwardly or outwardly rectifying KA responses, indicating that the calcium permeability of AMPA receptors is heterogeneous in the CP.

The inward rectification is a property of calcium-permeable AMPA receptors that requires the presence of intracellular polyamines such as spermine (Ozawa et al., 1998). Therefore we compared the degree of rectification in nucleated patches from IZ cells recorded in the absence or in the presence of $100 \mu \mathrm{M}$ spermine in the pipette solution. The KA-evoked response was tested in the presence of $100 \mu \mathrm{M} \mathrm{CTZ}$ to reduce AMPA receptor desensitization. The inward rectification was stronger in the presence of spermine $\left(\mathrm{G}_{+40}=0.20 \pm 0.05 ; n=2\right)$ than in the spermine-free condition $\left(\mathrm{G}_{+40}=0.39 \pm 0.09 ; n=3\right)$. These results indicate that the inward rectification of the KA-evoked responses of IZ cells depends on the presence of internal sperm- 




ine and support the idea that embryonic tangential IZ cells express calcium-permeable AMPA receptors.

\section{Distribution of cortical cells expressing calcium-permeable AMPA receptors}

Calcium-permeable AMPA receptors have a relatively high permeability to other divalent cations (Iino et al., 1990; Burnashev et al., 1992). Their high permeability to cobalt has been used to label cells expressing calcium-permeable AMPA/KA receptors and study their distribution (Pruss et al., 1991; Bardoul et al., 1998). We therefore examined the cobalt labeling induced by $250 \mu \mathrm{M}$ KA in embryonic cortical slice preparations at E13.5 and E14.5 (Fig. 5). The KA-induced cobalt accumulation was antagonized by the nonselective AMPA/KA antagonist DNQX (100 $\mu \mathrm{M})$ and the selective AMPA antagonist LY303070 (20 $\mu \mathrm{M})$; it was increased by the selective inhibitor of AMPA receptor desensitization CTZ $(100 \mu \mathrm{M})$, indicating that the cobalt labeling depends on the expression of AMPA receptors.

The distribution of the cobalt-labeled cells reproduce that of calbindin-positive cells (Fig. 1A). Cobalt-labeled cells are found in the IZ where we recorded inwardly rectifying KA responses, probably because of calcium-permeable AMPA receptors. These observations confirm that a population of cells in the IZ with similar distribution to the calbindin-positive cells express calcium-permeable AMPA receptors. Cobalt-labeled cells are also found in the preplate before the CP forms. At later stage, labeled cells divide in two rows outlining the $\mathrm{CP}$. We recorded in the $\mathrm{CP}$ a proportion of cells with inwardly rectifying KA re-

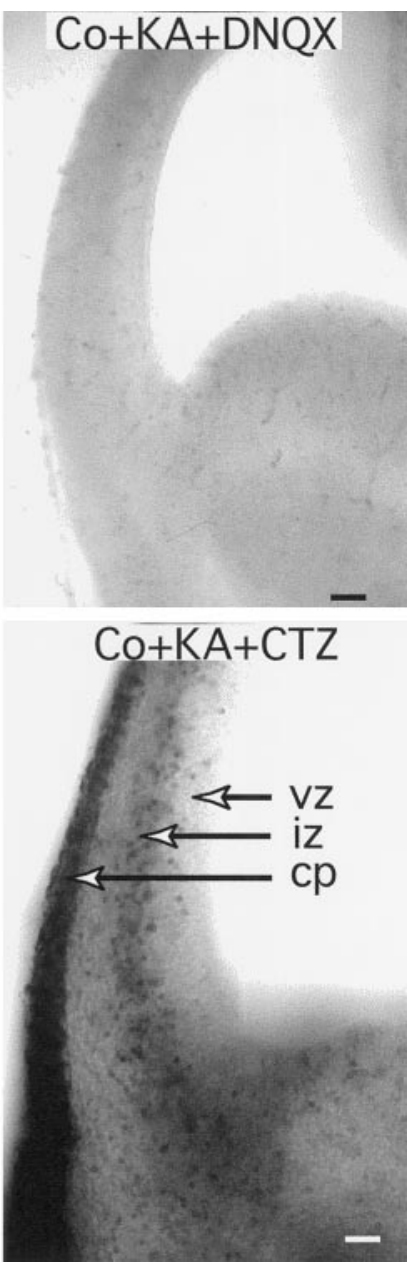

Figure 5. Kainate-induced cobalt loading in embryonic cortical slices. $A$, The KA-induced cobalt accumulation is tested in cortical slices from E14.5 mouse embryos. In control with $10 \mathrm{~mm}$ $\mathrm{CoCl}_{2}(\mathrm{Co})$, cells do not accumulate cobalt, except for a very few cells in cortex $(c x)$ and ganglionic eminence ( ge). In the presence of $250 \mu \mathrm{M} \mathrm{KA}$ and $10 \mathrm{~mm} \mathrm{CoCl}_{2}(C o+K A)$, cells in the cortical wall that strongly accumulate cobalt form a row in the lower half of the IZ (arrow) above the vZ, and more superficially, two rows outlining the developing CP (arrowheads). The KA-induced cobalt uptake is strongly antagonized by $100 \mu \mathrm{M}$ DNQX $(C o+$ $K A+D N Q X)$. Scale bar, $200 \mu \mathrm{m}$. $B$, KA-induced cobalt accumulation in cortical slices from E13.5 mouse embryos with $10 \mathrm{mM} \mathrm{CoCl} 2$ and $250 \mu \mathrm{M}$ $\mathrm{KA}$ in control $(\mathrm{Co}+K A)$, in the presence of $20 \mu \mathrm{M} \mathrm{LY} 303070(C o+K A+$ $L Y 303070$ ), and in the presence of 100 $\mu \mathrm{M} \mathrm{CTZ}(\mathrm{Co}+K A+C T Z)$. In control, labeled cells are seen in IZ and CP. LY303070 blocks cobalt accumulation. CTZ strengthens labeling in the IZ and CP; isolated labeled cells are occasionally observed in vz. Scale bar, $100 \mu \mathrm{m}$.

sponses probably due to calcium-permeable AMPA receptors, but their exact depth in the CP could not be estimated in our recording conditions.

\section{Immunocytochemical distribution of GluR1-3 AMPA subunits}

The absence of the edited form of GluR2 or the presence of its nonedited form has been correlated with the inward rectification (Bochet et al., 1994) and the high calcium permeability of AMPA receptors (Burnashev et al., 1992; Jonas et al., 1994; Geiger et al., 1995). During development a very small percentage of GluR2 subunit is found in the nonedited form (Burnashev et al., 1992). To examine whether IZ cells lack the GluR2 subunit or express its nonedited form, we investigated the distribution of AMPA subunits, using a specific antibody for GluR1 and a nonspecific antibody for GluR2 and GluR3 (GluR2/3) that recognizes both the edited and nonedited forms of GluR2 (Fig. 6).

In the lower IZ, we observed GluR1-positive cells, whose number increased from E13.5 to E14.5. No immunoreactivity to GluR2/3 subunits was detected in the IZ at either age. In the CP both GluR1 and GluR2/3 immunoreactivities were detected at E13.5 and E14.5. The expression of GluR1 and GluR2/3 subunits followed the maturation gradient in the $\mathrm{CP}$, being first expressed in the preplate and, after $\mathrm{CP}$ formation, in the marginal zone and subplate (Fig. 6A-D). Cells expressing GluR1 and cells expressing calbindin have similar distributions at either age. Doublelabeling experiments (Fig. 6E,F) show that most calbindin- 



\section{E13.5 IZ}
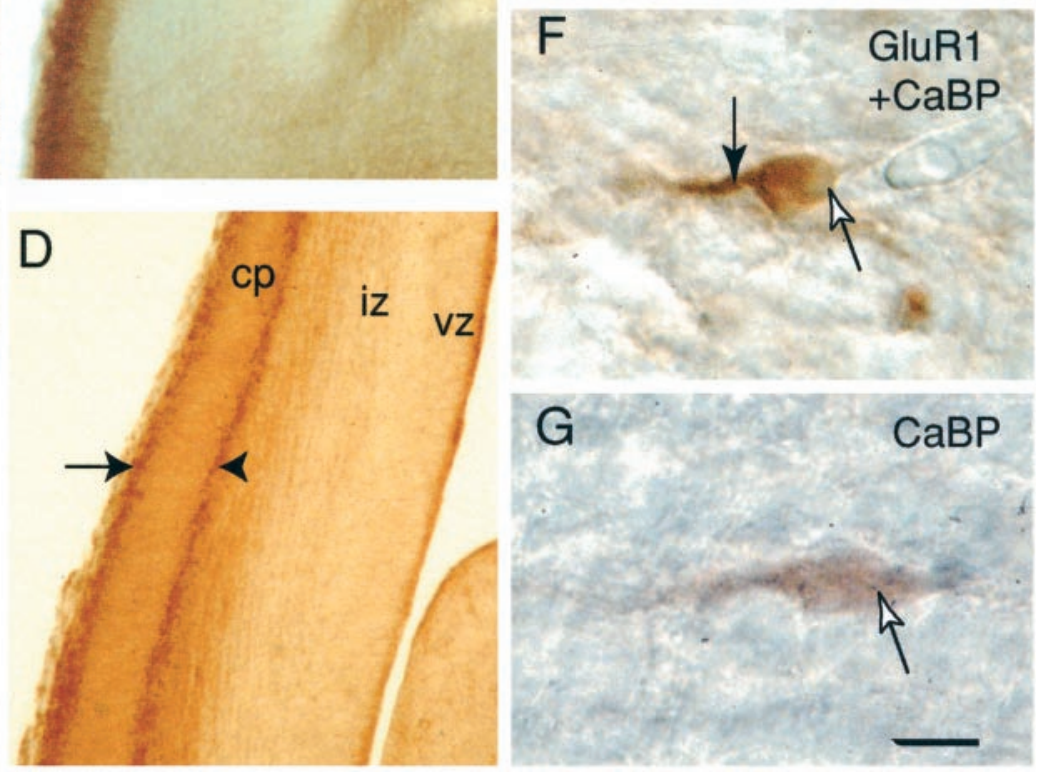

Figure 6. Distribution of GluR1-3 subunits in the embryonic cortical wall. $A-D$, One hundred-micrometer-thick coronal sections immunostained for the GluR1-3 subunits in E13.5 $(A, B)$ and E14.5 $(C, D)$ embryos. GluR1 subunit $(A, C)$ is expressed in the deeper half of the IZ and in two rows outlining the developing CP. Sparse labeled cells are observed in the vz. The density of GluR1-labeled cells in IZ appears to increase from E13.5 to E14.5. GluR2/3 subunits $(B, D)$ distribute in the preplate $(p p)$ at E13.5 $(B)$ and outline CP at E14.5 $(D)$ but are not observed in the IZ at these stages. $E$, $F$, Double-labeling experiments show that calbindin-positive cells in IZ of E13.5 embryos express GluR1. The GluR1-staining of IZ cells ( $E$ ) has a granular aspect and outlines cells suggesting membrane labeling (downward arrow). In contrast, the calbindin immunostaining of IZ cells $(G)$ is homogeneous, smooth, and fills the whole cell body (upward arrow). Double-labeled cells in the IZ $(F)$ show both the granular GluR1 labeling outlining a tangential process (downward arrow) and the smooth calbindin labeling of the cell body (upward arrow). Scale bars, $A, C, 150 \mu \mathrm{m} ; E, F, 10 \mu \mathrm{m}$.

positive IZ cells express GluR1, whereas some GluR1-positive IZ cells do not show calbindin immunoreactivity.

These results indicate that the inward rectification of the IZ cell AMPA receptors is likely caused by the lack of GluR2 subunit and not the presence of the nonedited form of GluR2. They also suggest that calbindin-positive IZ cells express AMPA receptors with high calcium permeability.

\section{Cortical fibers establish close contacts with IZ cells}

Millimolar concentrations of glutamate are required to activate AMPA receptors (Hestrin, 1992), whereas at micromolar concentrations desensitization occurs (Colquhoun et al., 1992). Millimolar concentrations are thought to be reached in the synaptic cleft after vesicular release (Clements et al., 1992). Fibers in IZ that likely originate in the cortex accumulate glutamate (Herrmann, 1996). We therefore searched at the ultrastructural level for spatial conjunctions between IZ cells and axons growing in this zone that might permit large, local elevations in glutamate concentration. In one set of experiments (Fig. 7), IZ cells were identified by their calbindin immunoreactivity, and in another set of experiments cortical efferent axons were DiI-labeled from the CP and photoconverted (Métin and Godement, 1996).

In IZ and subplate, we found neurites closely apposed to calbindin-positive cells (Fig. 7A,B). Appositions were remarkable by their length, which could cover a distance more than half the cell body diameter. Neurites facing calbindin-positive IZ cells contained clear vesicles, as described in lamellipodia, and were devoid of any other organite; we did not observe membrane thickenings resembling those observed in differentiating contacts (Gorgels, 1991). In these regions of close apposition, the distance between the neurites and IZ cells was $\sim 20 \mathrm{~nm}$ (in the range of the synaptic cleft) over long distances. In the IZ, DiI-labeled cortical axons surrounded cell bodies (Fig. 7C) in a way similar to that of neurites surrounding the calbindin-positive cells. Together with our previous observations in light microscopy showing DiIlabeled cortical axons close to calbindin-positive cell bodies (Métin and Godement, 1996), the present results suggest that the glutamate release from growing corticofugal axons might reach high local concentrations and efficiently activate AMPA receptors of tangential IZ cells. 

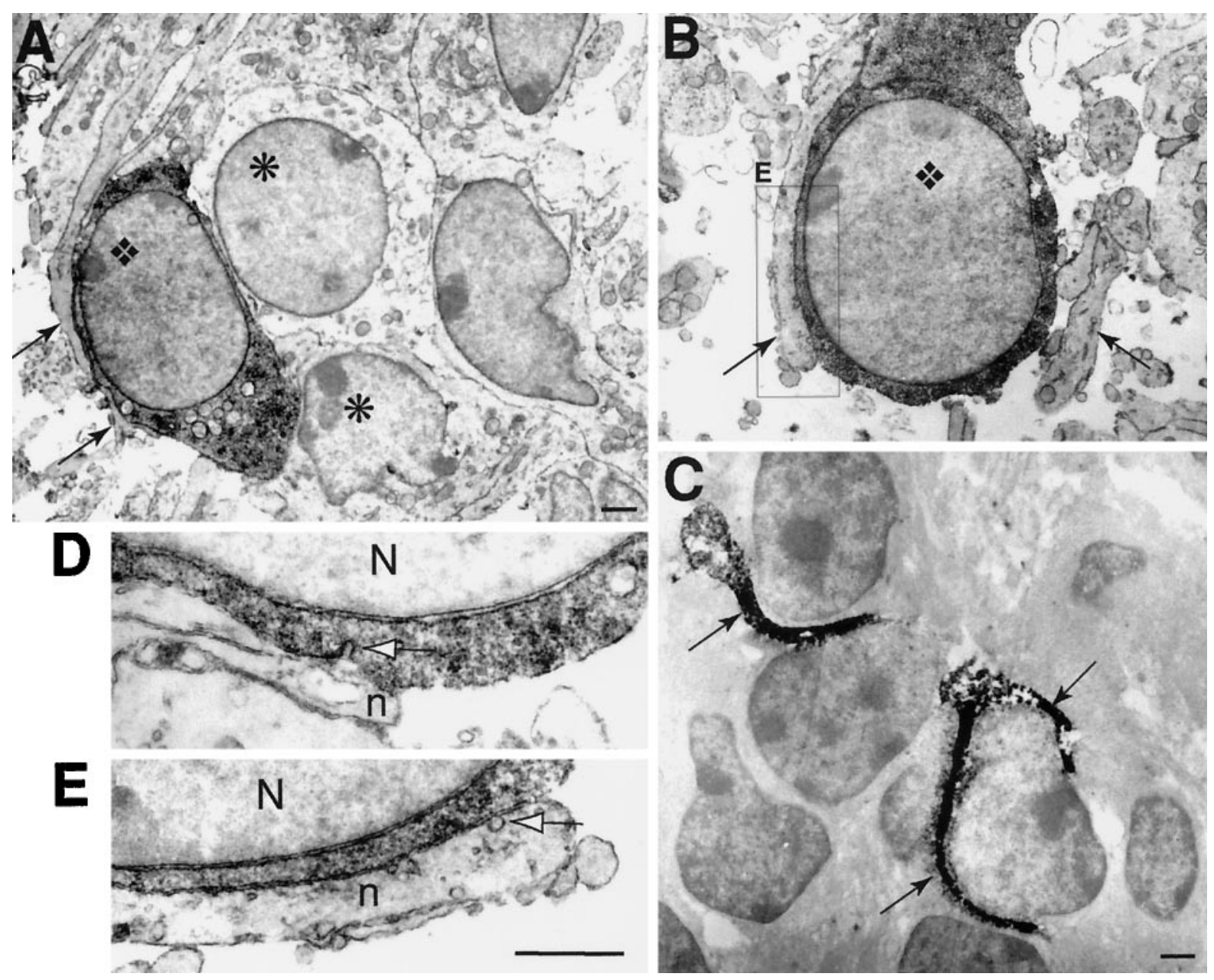

Figure 7. Relationships between neurites and calbindin-positive cells in IZ and CP, as revealed in electron microscopy. $A, B$, In both $\mathrm{CP}(A)$ and IZ $(B)$, calbindin-positive cells (diamond) filled by the dark DAB reaction product are in close contact with neurites (arrows) over long distance. In CP $(A)$, a calbindin-positive cell also contacts unlabeled cells (asterisk). $C$, In IZ, photoconverted DiI-labeled cortical fibers (DAB reaction product in black) cover cell bodies. $D, E$, At high magnification $(56,000 \times)$, no membrane thickening is visible in the region of close apposition between neurites $(n)$ and cell body of the dark-labeled calbindin-positive cells ( $N$, nucleus). In $D$, the plasmic membrane of the calbindin-positive cell is invaginated in a region apposed to a neurite (white arrow). In $E$ (detail of $B$ ), clear vesicles are visible in the neurite; one (white arrow) appears to fuse to the membrane apposed to the calbindin-positive cell. Scale bars: $A, C, 1 \mu \mathrm{m} ; D, E, 0.5 \mu \mathrm{m}$.

\section{Excitability of IZ cells}

Tangentially oriented cells in the IZ express neuronal markers like $\mathrm{GAD}_{67}, \mathrm{TuJ} 1, \mathrm{MAP}_{2 \mathrm{~J}}$, and calbindin (Cobas et al., 1991; Menezes and Luskin, 1994; Métin and Godement, 1996). To assess whether IZ cells can discharge action potentials, a property only found in neurons, we examined their excitability (Fig. 8).

On E13.5 and E14.5, IZ and CP cells had negative resting membrane potentials $(-66 \pm 4 \mathrm{mV} ; n=4)$ and a high input resistance $(7 \pm 6 \mathrm{G} \Omega, n=15$ for IZ cells; $4 \pm 4 \mathrm{G} \Omega, n=13$ for $\mathrm{CP}$ cells), suggesting that they are not coupled by gap junctions. Action potentials (50-60 mV amplitude) were recorded in CP cells in the whole-cell configuration $(n=3)$ after positive current injection (Fig. 8B3) and in the cell-attached configuration after bath application of $100 \mu \mathrm{M} \mathrm{KA}$. In tangential IZ cells recorded in the whole-cell configuration $(n=8)$, positive current injections generate only small depolarizations $(<20 \mathrm{mV}$; Fig. 8A3). In the cell-attached mode $(n=4)$, IZ cells did not generate action potentials.

Action potentials are generated by the activation of voltagegated sodium and calcium inward currents. We tested the ability of IZ and CP cells to generate voltage-gated inward currents using whole-cell recording (Fig. 8A4,B4). Both IZ and CP cells express a transient inward current with a threshold near $-40 \mathrm{mV}$ and a peak near $-10 \mathrm{mV}$, which was blocked by $1 \mu \mathrm{M}$ TTX $(n=$ 2 and 5, IZ and CP cells, respectively) showing that both IZ and $\mathrm{CP}$ cells express functional voltage-gated sodium channels. The amplitude of the TTX-sensitive current was significantly $(p<$ $0.001)$ larger in CP cells $(-310 \pm 303 \mathrm{pA} ; n=16)$ than in IZ cells $(-107 \pm 56 \mathrm{pA} ; n=14)$. In CP neurons, a residual inward current, recorded in the presence of TTX (Fig. 8B4), was blocked by $200 \mu \mathrm{M}$ cadmium $(n=3)$, suggesting that $\mathrm{CP}$ cells express also voltage-gated calcium channels.

Both IZ and CP cells express also a voltage-gated sustained outward current in control conditions when potassium ions were used as the main cation of the pipette solution. This outward current was reduced when cesium, a potassium channel blocker, was in the pipette solution (data not shown). This current, measured at $+40 \mathrm{mV}$, was significantly reduced by cesium both in IZ $(+230 \pm 62 \mathrm{pA}, n=5$ to $+20 \pm 8 \mathrm{pA}, n=4 ; p<0.005)$ and $\mathrm{CP}$ cells $(+455 \pm 262 \mathrm{pA}, n=8$ to $+15 \pm 5 \mathrm{pA}, n=5 ; p<0.001)$. These results indicate that tangential IZ cells can express sodium and potassium voltage-gated currents but cannot fire action po- 
A1 Intermediate zone

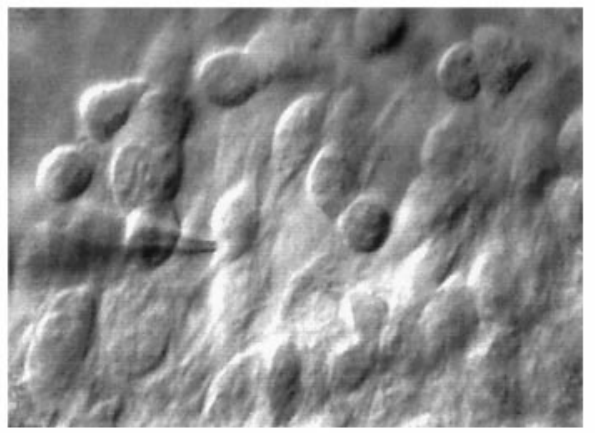

Figure 8. Excitability of embryonic (E14.5) IZ and CP cells. IZ $(A)$ and $\mathrm{CP}(B)$ cells are visualized in the living slice preparation by infrared video microscopy and recorded in the whole-cell configuration. Scale bar, $20 \mu \mathrm{m}$. $A 1$, In IZ the recorded cell belongs to an assembly of tangentially oriented cells with an elongated soma and a thicker neurite running dorsally. $\mathrm{B} 1$, In the $\mathrm{CP}$ the recorded cell has a spherical soma. $A 2, B 2$, The input resistance $\left(R_{\text {in }}\right)$ is obtained by applying current steps in the domain of linear response and calculating the slope of the $I-V$ curve $\left(R_{\text {in }}=19.5\right.$ and $2.8 \mathrm{G} \Omega$ for the IZ and the CP cell, respectively). $A 3, B 3$, Negative and positive current steps are applied $(b)$ to generate subthreshold and voltage-gated responses $(a)$. IZ and CP cells differ in their ability to generate spike discharge in response to positive current steps. $A 3$, In response to the larger positive current step, the IZ cell generates a small depolarization ( $a$, arrow). B3, In response to the larger positive current step, the $\mathrm{CP}$ cell generates an action potential (a, arrow). A4, B4, Whole-cell voltage-clamp recordings with cesium in the pipette solution. The cells are maintained at $-75 \mathrm{mV}$ in control medium. The current responses to six voltage steps between -55 and +45 $\mathrm{mV}$ are superimposed after leak subtraction. Inset, In control medium, a voltage step to $-15 \mathrm{mV}$ evokes a transient inward current (ctrl), which is absent in TTX $(T T X)$. In the IZ cell $(A 4)$, TTX completely blocks the inward current. In the $\mathrm{CP}$ cell $(B 4)$, a residual slow inward current remains in TTX; this residual current is blocked by $200 \mu \mathrm{M}$ cadmium (data not shown).

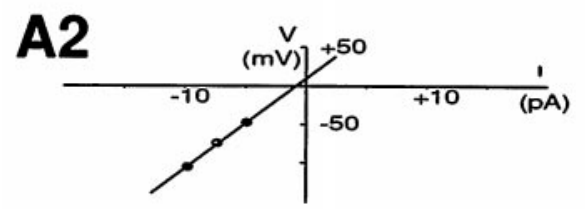

\section{A3}
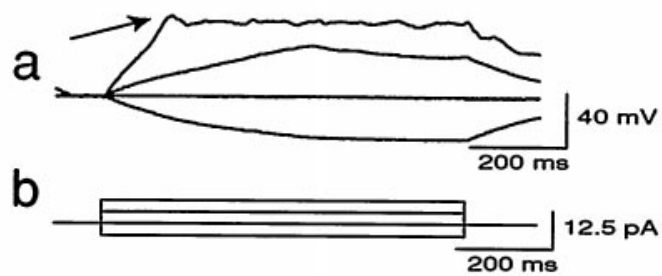

A4

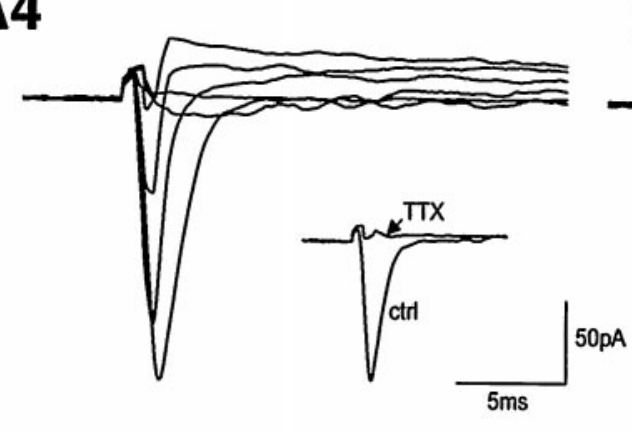

\section{B1}

\section{Cortical plate}
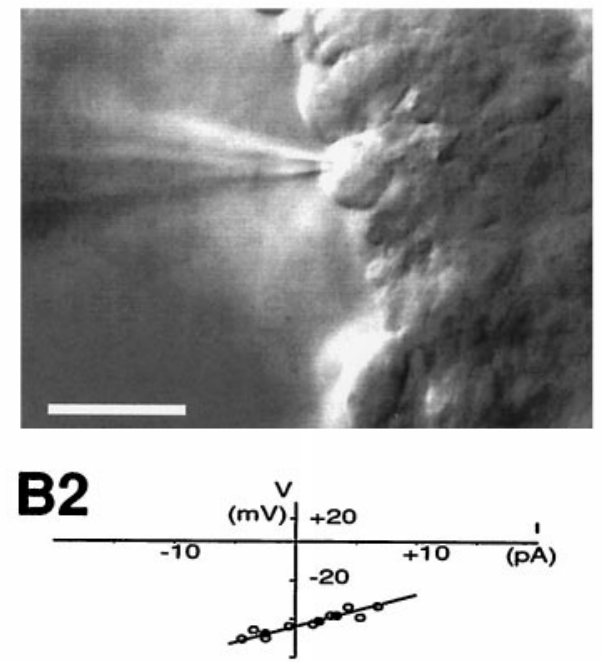

B3

a

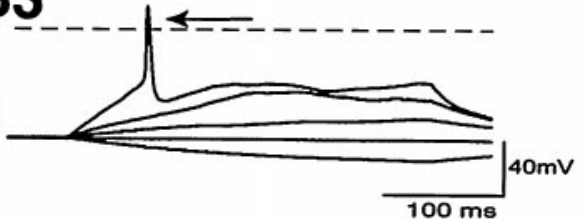

$b$

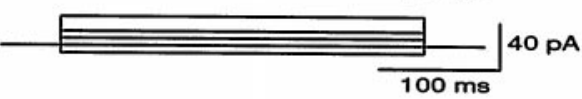

B4 $50 p A$

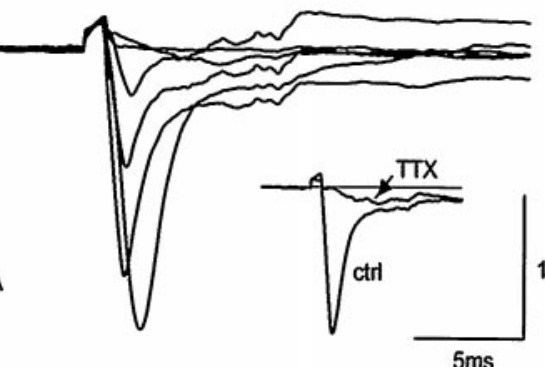

$100 \mathrm{pA}$

tentials at E13.5-E14.5, probably as a result of a lower density of sodium channels than $\mathrm{CP}$ cells.

\section{DISCUSSION}

We have studied the expression of glutamate receptors by cells of the IZ and CP in the embryonic cortex when cortical axons elongate in the IZ among calbindin-positive tangential cells. We show that tangential IZ cells express calcium-permeable AMPA receptors and are tightly apposed to neurites containing clear vesicles. This leads us to propose that before the differentiation of synapses, glutamate AMPA receptors of IZ cells could be efficiently activated by the vesicular release of glutamate from closely apposed corticofugal neurites. The entry of calcium via these receptors might control the migration and fate of tangential IZ cells and modulate their influence on cortical development (Fig. 9).

\section{Calcium-permeable AMPA receptors in embryonic cortex}

We show that at E13.5 and E14.5 embryonic cortical IZ cells express AMPA but not NMDA glutamate receptors, unlike CP cells, which express both receptor types (LoTurco et al., 1991). Our results indicate that bath applications of KA activate AMPA receptors in IZ and $\mathrm{CP}$ cells because: (1) responses to the application of KA are sustained and do not undergo complete desensitization as do responses of $\mathrm{KA}$ receptors (Paternain et al., 1995); (2) the response to KA is enhanced by CTZ, a selective inhibitor of AMPA receptor desensitization (Partin et al., 1993); and (3) the response to KA is completely antagonized by LY303070, a selective noncompetitive antagonist of AMPA receptors (Bleakman et al., 1996).

We show that by E13.5-E14.5, AMPA receptors with different 


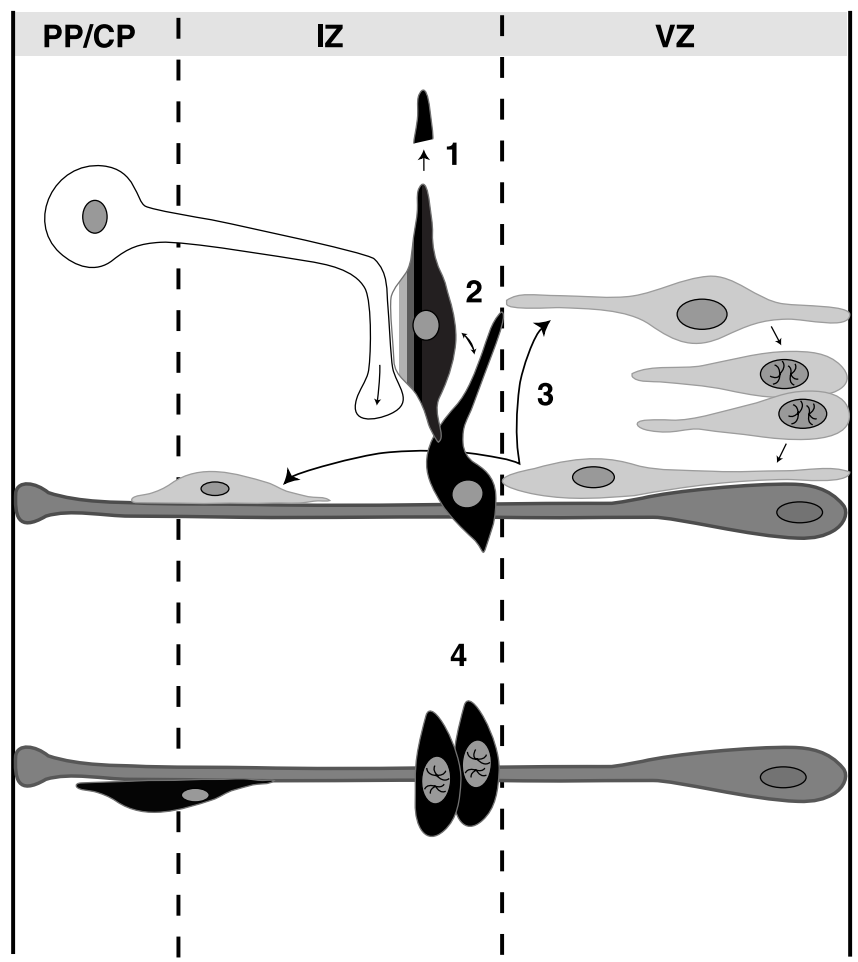

Figure 9. Schematic representation of possible functional consequences of the interactions between tangential IZ cells and growing corticofugal axons in embryonic cortex. The activation of the calcium-permeable AMPA receptors of GABAergic tangential IZ cells (black) by the glutamate release from the nearby growing axons of $\mathrm{CP}$ cells (white) may control the tangential migration of the IZ cells (1), the release of GABA, and the subsequent activation of the $\mathrm{GABA}_{\mathrm{A}}$ receptors expressed by neighboring IZ cells (2). The GABA release by IZ cells could also control the proliferation (3) of the VZ cells ( gray) and the migration of cortical precursors on the radial glia (dark gray). CP cells could therefore influence the proliferation in VZ through the activation of the tangential IZ cells. The AMPA activation of IZ cells could also control their survival and influence their differentiation as proliferating cells in the lower IZ (4) before their migration in the cortex as a subpopulation of GABAergic interneurons.

calcium permeabilities are differentially expressed in cells of different cortical layers, as observed in the adult neocortex (Jonas et al., 1994; Angulo et al., 1997; Itazawa et al., 1997). The expression of calcium-permeable AMPA receptors by IZ and CP cells is attested by: (1) the strong inward rectification of their KA response $I-V$ curve previously correlated with high calcium permeability (Iino et al., 1990, 1994; Hollmann et al., 1991; Hume et al., 1991); (2) the importance of spermine for the inward rectification (see Ozawa et al., 1998); (3) the absence of GluR2 subunit in IZ (Burnashev et al., 1992; Bochet et al., 1994; Geiger et al., 1995); and (4) the KA-induced cobalt accumulation in IZ typical of the weakly selective calcium-permeable AMPA receptors (Iino et al., 1990; Sensi et al., 1999).

In the $\mathrm{CP}$, cells with inwardly rectifying $\mathrm{KA}$ responses probably correspond to those which accumulate cobalt. They could represent precursors of early generated fast-spiking and regularspiking GABAergic interneurons that express similar AMPA receptors (Jonas et al., 1994; Angulo et al., 1997; Cauli et al., 1997; Itazawa et al., 1997). We also recorded CP cells with outwardly rectifying $\mathrm{KA}$ responses, correlated with the presence of GluR2/3 in the CP, and typical of AMPA receptors with low calcium permeability. We observed GluR2/3 immunostaining in layers that contain the earliest generated cortical neurons, the preplate and, slightly later, the subplate and marginal zone. Cells with outwardly rectifying KA responses may correspond to early generated pyramidal neurons or to regular spiking interneurons that express the same AMPA receptors in adult cortex (Jonas et al., 1994; Angulo et al., 1997; Itazawa et al., 1997).

We found that tangential IZ cells give relatively uniform responses to KA. They express AMPA receptors with high calcium permeability and probably correspond to the IZ cells that accumulate cobalt in the presence of KA. The absence of GluR2/3 staining in IZ suggests that the calcium permeability of AMPA receptors of IZ cells does not depend on the presence of the nonedited form of GluR2 but on the absence of the edited form of GluR2 (Burnashev et al., 1992).

\section{Do IZ cell functional properties identify neuronal or glial cells?}

The high input resistance of IZ cells suggests that, unlike the VZ cells, they are not coupled through gap junctions (LoTurco and Kriegstein, 1991) and probably do not proliferate at this stage.

Because IZ cells express $\mathrm{MAP}_{2 \mathrm{~J}}$, Tuj1, and $\mathrm{GAD}_{67}$, which are markers of differentiating neurons (Menezes and Luskin, 1994; Métin and Godement, 1996; Tamamaki et al., 1997), we asked whether the functional properties of IZ cells could be characteristic of immature migrating neurons. The IZ cells express TTXsensitive channels but cannot fire action potentials like immature migrating Tuj1-positive neurons (Stewart et al., 1999). They also express calcium-permeable AMPA receptors, as do GABAergic interneurons in adult cortex (Jonas et al., 1994; Itazawa et al., 1997). In embryonic cortex, GABAergic neurons and calbindinpositive cells show similar morphology and distribution (Van Eden et al., 1989; Cobas et al., 1991; Del Rio et al., 1992; DeDiego et al., 1994). In the IZ of E13.5-E14.5 embryos, we find a similar distribution of cells with calcium-permeable AMPA receptors, of cells that accumulate cobalt, of calbindin-positive cells, and of cells expressing the GluR1 subunit but lacking the GluR2 subunit. In addition, GluR1 and calbindin are coexpressed in a fraction of IZ cells. These observations suggest that embryonic IZ cells may represent immature, tangentially migrating calbindin-positive GABAergic neurons expressing calcium-permeable AMPA receptors. Accordingly, in Dlx mutants that lack tangentially migrating IZ cells, the number of GABAergic interneurons is reduced in the adult neocortex (Anderson et al., 1997).

We cannot completely exclude the possibility that IZ cells are glial progenitors that also express calcium-permeable AMPA receptors (Patneau et al., 1994; Puchalski et al., 1994), do not fire action potentials, but express TTX-sensitive sodium channels (Sontheimer and Waxman, 1993). At the stages we have studied, neuronal and glial lineages have already diverged in the cortical wall (Luskin et al., 1988; Grove et al., 1993). Oligodendrocyte progenitors migrate from restricted areas in the ventral neural tube and begin to reach the corticostriatal angle at E13.5 (Pringle and Richardson, 1993; Timsit et al., 1995; Spassky et al., 1998). They could pass to the lower IZ where the subventricular zone differentiates and where they are believed to proliferate (Levison and Goldman, 1993).

\section{Tangential migration of IZ cells}

The tangential IZ cells we recorded probably originate in the basal telencephalon (Anderson et al., 1997; Wichterle et al., 1999). They express glutamate AMPA receptors with high calcium permeability. Therefore, the glutamate-mediated calcium 
influx might control their motility and regulate their tangential migration (Gomez et al., 1995; Gu and Spitzer, 1995; Komuro and Rakic, 1996; Gomez and Spitzer, 1999). Because we recorded cells with similar morphology and glutamate receptors in the IZ, it would be important to determine whether tangential IZ cells represent a homogenous (neuronal) or a heterogeneous (neuronal and oligodendrocyte progenitors) population. The AMPA receptors of IZ cells could therefore mediate specific functional interactions with neighboring tangential cells that differ from those occurring in other cortical cells with NMDA-dependent migration along radial glia (Komuro and Rakic, 1993).

\section{Activation of AMPA receptors in IZ cells}

The natural ligand of AMPA receptor, glutamate, is probably accumulated by axons in the IZ that express a glutamate transporter (Furuta et al., 1997). It seems possible that exocytosis of glutamate (Soeda et al., 1997) could occur from growing axons and cones before synapse formation, as suggested by FM1-43 labeling (Dai and Peng, 1996), and the distribution of the SNARE and sec6/8 complexes during axon elongation (Igarashi et al., 1997; Hazuka et al., 1999). We have shown that neurites, including some arising from the $\mathrm{CP}$, form close contacts with calbindinpositive cells in the IZ and CP. We have also observed small vesicles similar to those found in growth cones (Gorgels, 1991; Auladell et al., 1995) in the neurites facing the calbindin-positive cells. Concentrations of glutamate released by growing corticofugal axons could, therefore, reach the millimolar levels necessary to activate AMPA receptors and initiate calcium influx in tangential IZ cells.

\section{Control of survival and cell differentiation}

Calcium influx through AMPA receptors could also have longterm effects on the survival and fate of IZ cells. The AMPA receptor activation could induce an influx of calcium and zinc and trigger IZ cell death (Weiss et al., 1993; Sensi et al., 1999). However, the high levels of calbindin that IZ cells express might protect them from calcium cytotoxicity (Mattson et al., 1991). Calcium entry could also modulate the differentiation of IZ cells into mature cortical cells. In mature brains, the white matter contains sparse GABAergic neurons, generated at the earliest stages of corticogenesis (Chun and Shatz, 1989; Kostovic and Rakic, 1990; Cobas et al., 1991). IZ cells could therefore stop their tangential migration and differentiate beneath the cortex. IZ cells could also proliferate in the lower IZ before migrating to the $\mathrm{CP}$ and giving rise to cortical GABAergic interneurons, oligodendrocytes, and astrocytes, as observed in the cerebellum (Zhang and Goldman, 1996) and suggested from the Dlx mutants (Anderson et al., 1997) and graft experiments (Wichterle et al., 1999). Finally, the activation of calcium-permeable AMPA receptors could also induce the release of GABA by IZ cells and activate the $\mathrm{GABA}_{\mathrm{A}}$ receptors we found in IZ cells. These $\mathrm{GABA}_{\mathrm{A}}$-mediated interactions may be involved in the cortical cell proliferation (LoTurco et al., 1995), migration, and motility (Behar et al., 1996).

In conclusion, our observations support the hypothesis of a local glutamatergic communication, based on close appositions between elongating cortical axons and GABAergic IZ cells, which occurs long before the differentiation of synapses in the developing neocortex. These interactions would differ from the more diff use humoral effect of glutamate previously described in brain development. They occur outside the cortical plate and could be critical for the cortex development.

\section{REFERENCES}

Altman J, Bayer SA (1990) Horizontal compartmentation in the germinal matrices and intermediate zone of the rat cerebral cortex. Exp Neurol 107:36-47.

Anderson SA, Eisenstat DD, Shi L, Rubenstein JL (1997) Interneuron migration from basal forebrain to neocortex: dependence on Dlx genes. Science 278:474-476.

Angulo MC, Lambolez B, Audinat E, Hestrin S, Rossier J (1997) Subunit composition, kinetic, and permeation properties of AMPA receptors in single neocortical nonpyramidal cells. J Neurosci 17:6685-6696.

Auladell C, Martinez A, Alcantara S, Super H, Soriano E (1995) Migrating neurons in the developing cerebral cortex of the mouse send callosal axons. Neuroscience 64:1091-1103.

Bahn S, Volk B, Wisden W (1994) Kainate receptor gene expression in the developing rat brain. J Neurosci 14:5525-5547.

Bardoul M, Levallois C, Konig N (1998) Functional AMPA/kainate receptors in human embryonic and foetal central nervous system. J Chem Neuroanat 14:79-85.

Beatus P, Lendahl U (1998) Notch and neurogenesis. J Neurosci Res 54:125-136.

Behar TN, Li YX, Tran HT, Ma W, Dunlap V, Scott C, Barker JL (1996) GABA stimulates chemotaxis and chemokinesis of embryonic cortical neurons via calcium-dependent mechanisms. J Neurosci 16:1808-1818.

Behar TN, Scott CA, Greene CL, Wen X, Smith SV, Maric D, Liu QY, Colton CA, Barker JL (1999) Glutamate acting at NMDA receptors stimulates embryonic cortical neuronal migration. J Neurosci 19:4449-4461.

Bettler B, Boulter J, Hermans-Borgmeyer I, O'Shea-Greenfield A, Deneris ES, Moll C, Borgmeyer U, Hollmann M, Heinemann S (1990) Cloning of a novel glutamate receptor subunit, GluR5: expression in the nervous system during development. Neuron 5:583-595.

Bleakman D, Ballyk BA, Schoepp DD, Palmer AJ, Bath CP, Sharpe EF, Woolley ML, Bufton HR, Kamboj RK, Tarnawa I, Lodge D (1996) Activity of 2,3-benzodiazepines at native rat and recombinant human glutamate receptors in vitro: stereospecificity and selectivity profiles. Neuropharmacology 35:1689-1702.

Bochet P, Audinat E, Lambolez B, Crepel F, Rossier J, Iino M, Tsuzuki K, Ozawa S (1994) Subunit composition at the single-cell level explains functional properties of a glutamate-gated channel. Neuron 12:383-388.

Brew H, Attwell D (1987) Electrogenic glutamate uptake is a major current carrier in the membrane of axolotl retinal glial cells. Nature 327:707-709.

Burnashev N, Monyer H, Seeburg PH, Sakmann B (1992) Divalent ion permeability of AMPA receptor channels is dominated by the edited form of a single subunit. Neuron 8:189-198.

Cauli B, Audinat E, Lambolez B, Angulo MC, Ropert N, Tsuzuki K, Hestrin S, Rossier J (1997) Molecular and physiological diversity of cortical nonpyramidal cells. J Neurosci 17:3894-3906.

Chun JJM, Shatz CJ (1989) Interstitial cells of the adult neocortical white matter are the remnant of the early generated subplate neuron population. J Comp Neurol 282:555-569.

Clements JD, Lester RA, Tong G, Jahr CE, Westbrook GL (1992) The time course of glutamate in the synaptic cleft. Science 258:1498-1501.

Cobas A, Fairen A, Alvarezbolado G, Sanchez MP (1991) Prenatal development of the intrinsic neurons of the rat neocortex: a comparative study of the distribution of GABA-immunoreactive cells and the GABAA receptor. Neuroscience 40:375-397.

Colquhoun D, Jonas P, Sakmann B (1992) Action of brief pulses of glutamate on AMPA/kainate receptors in patches from different neurones of rat hippocampal slices. J Physiol (Lond) 458:261-287.

Dai Z, Peng HB (1996) Dynamics of synaptic vesicles in cultured spinal cord neurons in relationship to synaptogenesis. Mol Cell Neurosci $7: 443-452$.

DeDiego I, Smith-Fernandez A, Fairen A (1994) Cortical cells that migrate beyond area boundaries: characterization of an early neuronal population in the lower intermediate zone of prenatal rats. Eur J Neurosci 6:983-997.

Del Rio J A, Soriano E, Ferrer I (1992) Development of GABAImmunoreactivity in the Neocortex of the Mouse. J Comp Neurol 326:501-526.

Durand GM, Zukin RS (1993) Developmental regulation of mRNAs encoding rat brain kainate/AMPA receptors: a northern analysis study. J Neurochem 61:2239-2246. 
Flanagan JG, Vanderhaeghen P (1998) The ephrins and Eph receptors in neural development. Annu Rev Neurosci 21:309-345.

Furuta A, Rothstein JD, Martin LJ (1997) Glutamate transporter protein subtypes are expressed differentially during rat CNS development. J Neurosci 17:8363-8375.

Gallo V, Zhou JM, McBain CJ, Wright P, Knutson PL, Armstrong RC (1996) Oligodendrocyte progenitor cell proliferation and lineage progression are regulated by glutamate receptor-mediated $\mathrm{K}+$ channel block. J Neurosci 16:2659-2670.

Geiger JR, Melcher T, Koh DS, Sakmann B, Seeburg PH, Jonas P, Monyer H (1995) Relative abundance of subunit mRNAs determines gating and $\mathrm{Ca}^{2+}$ permeability of AMPA receptors in principal neurons and interneurons in rat CNS. Neuron 15:193-204.

Gomez TM, Spitzer NC (1999) In vivo regulation of axon extension and pathfinding by growth-cone calcium transients. Nature 397:350-355.

Gomez TM, Snow DM, Letourneau PC (1995) Characterization of spontaneous calcium transients in nerve growth cones and their effect on growth cone migration. Neuron 14:1233-1246.

Gorgels TG (1991) Outgrowth of the pyramidal tract in the rat cervical spinal cord: growth cone ultrastructure and guidance. J Comp Neurol 306:95-116.

Grove EA, Williams BP, Li DQ, Hajihosseini M, Friedrich A, Price J (1993) Multiple restricted lineages in the embryonic rat cerebral cortex. Development 117:553-561.

Gu X, Spitzer NC (1995) Distinct aspects of neuronal differentiation encoded by frequency of spontaneous $\mathrm{Ca}^{2+}$ transients. Nature 375:784-787.

Hazuka CD, Foletti DL, Hsu SC, Kee Y, Hopf FW, Scheller RH (1999) The sec6/8 complex is located at neurite outgrowth and axonal synapseassembly domains. J Neurosci 19:1324-1334.

Herb A, Burnashev N, Werner P, Sakmann B, Wisden W, Seeburg PH (1992) The KA-2 subunit of excitatory amino acid receptors shows widespread expression in brain and forms ion channels with distantly related subunits. Neuron 8:775-785.

Herrmann K (1996) Differential distribution of AMPA receptors and glutamate during pre- and postnatal development in the visual cortex of ferrets. J Comp Neurol 375:1-17.

Hestrin S (1992) Activation and desensitization of glutamate-activated channels mediating fast excitatory synaptic currents in the visual cortex. Neuron 9:991-999.

Hollmann M, Heinemann S (1994) Cloned glutamate receptors. Annu Rev Neurosci 17:31-108.

Hollmann M, Hartley M, Heinemann S (1991) $\mathrm{Ca}^{2+}$ permeability of KA-AMPA-gated glutamate receptor channels depends on subunit composition. Science 252:851-853.

Hume RI, Dingledine R, Heinemann SF (1991) Identification of a site in glutamate receptor subunits that controls calcium permeability. Science 253:1028-1031.

Igarashi M, Tagaya M, Komiya Y (1997) The soluble $N$-ethylmaleimidesensitive factor attached protein receptor complex in growth cones: molecular aspects of the axon terminal development. J Neurosci 17:1460-1470.

Iino M, Ozawa S, Tsuzuki K (1990) Permeation of calcium through excitatory amino acid receptor channels in cultured rat hippocampal neurones. J Physiol (Lond) 424:151-165.

Iino M, Mochizuki S, Ozawa S (1994) Relationship between calcium permeability and rectification properties of AMPA receptors in cultured rat hippocampal neurons. Neurosci Lett 173:14-6.

Itazawa SI, Isa T, Ozawa S (1997) Inwardly rectifying and $\mathrm{Ca}^{2+}$ permeable AMPA-type glutamate receptor channels in rat neocortical neurons. J Neurophysiol 78:2592-2601.

Jonas P, Racca C, Sakmann B, Seeburg PH, Monyer H (1994) Differences in $\mathrm{Ca}^{2+}$ permeability of AMPA-type glutamate receptor channels in neocortical neurons caused by differential GluR-B subunit expression. Neuron 12:1281-1289.

Komuro H, Rakic P (1993) Modulation of neuronal migration by NMDA receptors. Science 260:95-97.

Komuro H, Rakic P (1996) Intracellular $\mathrm{Ca}^{2+}$ fluctuations modulate the rate of neuronal migration. Neuron 17:275-285.

Kostovic I, Rakic P (1990) Developmental history of the transient subplate zone in the visual and somatosensory cortex of the macaque monkey and human brain. J Comp Neurol 297:441-470.

Laurie DJ, Seeburg PH (1994) Regional and developmental heterogeneity in splicing of the rat brain NMDAR1 mRNA. J Neurosci 14:3180-3194.
Levison SW, Goldman JE (1993) Both oligodendrocytes and astrocytes develop from progenitors in the subventricular zone of postnatal rat forebrain. Neuron 10:201-212.

LoTurco JJ, Kriegstein AR (1991) Clusters of coupled neuroblasts in embryonic neocortex. Science 252:563-566.

LoTurco JJ, Blanton MG, Kriegstein AR (1991) Initial expression and endogenous activation of NMDA channels in early neocortical development. J Neurosci 11:792-799.

LoTurco JJ, Owens DF, Heath MJ, Davis MB, Kriegstein AR (1995) GABA and glutamate depolarize cortical progenitor cells and inhibit DNA synthesis. Neuron 15:1287-1298.

Luskin MB, Pearlman AL, Sanes JR (1988) Cell lineage in the cerebral cortex of the mouse studied in vivo and in vitro with a recombinant retrovirus. Neuron 1:635-647.

Ma W, Barker JL (1998) GABA, GAD, and GABA(A) receptor alpha4, beta1, and gamma1 subunits are expressed in the late embryonic and early postnatal neocortical germinal matrix and coincide with gliogenesis. Microsc Res Tech 40:398-407.

Mattson MP, Wang H, Michaelis EK (1991) Developmental expression, compartmentalization, and possible role in excitotoxicity of a putative NMDA receptor protein in cultured hippocampal neurons. Brain Res 565:94-108.

Mehler MF, Mabie PC, Zhang D, Kessler JA (1997) Bone morphogenetic proteins in the nervous system. Trends Neurosci 20:309-317.

Menezes JRL, Luskin MB (1994) Expression of neuron-specific tubulin defines a novel population in the proliferative layers of the developing telencephalon. J Neurosci 14:5399-5416.

Métin C, Godement P (1996) The ganglionic eminence may be an intermediate target for corticofugal and thalamocortical axons. J Neurosci 16:3219-3235.

Miller B, Chou L, Finlay BL (1993) The early development of thalamocortical and corticothalamic projections. J Comp Neurol 335:16-41.

Molnar Z, Adams R, Blakemore C (1998) Mechanisms underlying the early establishment of thalamocortical connections in the rat. J Neurosci 18:5723-5745.

Monyer H, Seeburg PH, Wisden W (1991) Glutamate-operated channels: developmentally early and mature forms arise by alternative splicing. Neuron 6:799-810.

Owen AD, Bird MM (1997) Role of glutamate in the regulation of the outgrowth and motility of neurites from mouse spinal cord neurons in culture. J Anat 191:301-307.

Ozawa S, Kamiya H, Tsuzuki K (1998) Glutamate receptors in the mammalian central nervous system. Prog Neurobiol 54:581-618.

Partin KM, Patneau DK, Winters CA, Mayer ML, Buonanno A (1993) Selective modulation of desensitization at AMPA versus kainate receptors by cyclothiazide and concanavalin A. Neuron 11:1069-1082.

Paternain AV, Morales M, Lerma J (1995) Selective antagonism of AMPA receptors unmasks kainate receptor-mediated responses in hippocampal neurons. Neuron 14:185-189.

Patneau DK, Wright PW, Winters C, Mayer ML, Gallo V (1994) Glial cells of the oligodendrocyte lineage express both kainate- and AMPApreferring subtypes of glutamate receptor. Neuron 12:357-371.

Pringle NP, Richardson WD (1993) A singularity of PDGF alphareceptor expression in the dorsoventral axis of the neural tube may define the origin of the oligodendrocyte lineage. Development 117:525-533.

Pruss RM, Akeson RL, Racke MM, Wilburn JL (1991) Agonistactivated cobalt uptake identifies divalent cation-permeable kainate receptors on neurons and glial cells. Neuron 7:509-518.

Puchalski RB, Louis JC, Brose N, Traynelis SF, Egebjerg J, Kukekov V, Wenthold RJ, Rogers SW, Lin F, Moran T, Morrison JH, Heinemann SF (1994) Selective RNA editing and subunit assembly of native glutamate receptors. Neuron 13:131-147.

Schurr A, Payne RS, Miller JJ, Rigor BM (1997) Brain lactate, not glucose, fuels the recovery of synaptic function from hypoxia upon reoxygenation: an in vitro study. Brain Res 744:105-11.

Sensi SL, Yin HZ, Carriedo SG, Rao SS, Weiss JH (1999) Preferential $\mathrm{Zn}^{2+}$ influx through $\mathrm{Ca}^{2+}$-permeable AMPA/kainate channels triggers prolonged mitochondrial superoxide production. Proc Natl Acad Sci USA 96:2414-2419.

Soeda H, Tatsumi H, Katayama Y (1997) Neurotransmitter release from growth cones of rat dorsal root ganglion neurons in culture. Neuroscience 77:1187-1199. 
Sontheimer H, Waxman SG (1993) Expression of voltage-activated ion channels by astrocytes and oligodendrocytes in the hippocampal slice. J Neurophysiol 70:1863-1873.

Spassky N, Goujet-Zalc C, Parmantier E, Olivier C, Martinez S, Ivanova A, Ikenaka K, Macklin W, Cerruti I, Zalc B, Thomas JL (1998) Multiple restricted origin of oligodendrocytes. J Neurosci 18:8331-8343.

Stewart RR, Zigova T, Luskin MB (1999) Potassium currents in precursor cells isolated from the anterior subventricular zone of the neonatal rat forebrain. J Neurophysiol 81:95-102.

Takahashi T, Nowakowski RS, Caviness VS (1995) The cell cycle of the pseudostratified ventricular epithelium of the embryonic murine cerebral wall. J Neurosci 15:6046-6057.

Tamamaki N, Fujimori KE, Takauji R (1997) Origin and route of tangentially migrating neurons in the developing neocortical intermediate zone. J Neurosci 17:8313-8323.

Tan SS, Kalloniatis M, Sturm K, Tam PP, Reese BE, Faulkner-Jones B (1998) Separate progenitors for radial and tangential cell dispersion during development of the cerebral neocortex. Neuron 21:295-304.
Tessier-Lavigne M, Goodman CS (1996) The molecular biology of axon guidance. Science 274:1123-1133.

Timsit S, Martinez S, Allinquant B, Peyron F, Puelles L, Zalc B (1995) Oligodendrocytes originate in a restricted zone of the embryonic ventral neural tube defined by DM-20 mRNA expression. J Neurosci 15:1012-1024.

Van Eden CG, Mrzljak L, Voorn P, Uylings HBM (1989) Prenatal developmental of GABA-ergic neurons in the neocortex of the rat. J Comp Neurol 289:213-227.

Weiss JH, Hartley DM, Koh JY, Choi DW (1993) AMPA receptor activation potentiates zinc neurotoxicity. Neuron 10:43-49.

Wichterle H, Garcia-Verdugo JM, Herrera DG, Alvarez-Buylla A (1999) Young neurons from medial ganglionic eminence disperse in adult and embryonic brain. Nat Neurosci 2:461-466.

Zhang L, Goldman J (1996) Generation of cerebellar interneurons from dividing progenitors in white matter. Neuron 16:47-54.

Zheng JQ, Felder M, Connor JA, Poo MM (1994) Turning of nerve growth cones induced by neurotransmitters. Nature 368:140-144. 